JPdK Volume 3 Nomor 1 Tahun 2021 Halaman 7-12

JURNAL PENDIDIKAN dan KONSELING

Research \& Learning in Faculty of Education

\title{
Penerapan Metode Silaba Untuk Meningkatkan Keterampilan Membaca Permulaan Siswa Sekolah Dasar
}

\author{
Suci Silvia $^{1}$, Putri Hana Pebriana ${ }^{2}$, Sumianto 3 \\ Program Pendidikan Guru Sekolah Dasar \\ Fakultas Ilmu Pendidikan \\ Universitas Pahlawan Tuanku Tambusai \\ Email :sucisilvia888@gmail.com
}

\begin{abstract}
Abstrak
Penelitian ini dilatar belakangi rendahnya keterampilan membaca permulaan siswa kelas I SDN 012 Bengkong Batam. Salah satu solusi utuk mengatasi masalah ini adalah dengan menerapkan metode silaba. Tujuan penelitian ini untuk meningkatkan keterampilan membaca siswa kelas I pada tema Keluargaku dengan menggunakan metode silaba. Metode peelitian ini adalah Penelitian Tindakan Kelas (PTK) yanng dilaksanakan dalam dua siklus. Setiap siklus terdiri dari dua pertemuan dan empat tahapan yakni perencanaan, pelaksanaan, observasi, refleksi, dan waktu penelitian dilaksanakan pada 20 November 2019- 28 November 2019. Subjek penelitian ini siswa kelas I yaitu berjumlah 40 orang. Teknik pengumpulan berupa dokumentasi, observasi dan tes. Hasil penelitian ini disimpulkan bahwa keterampilan membaca permulaan siswa dengan tema Keluarhalu pada siklus I tergolong kurang efektif dengan presentase ketuntasan siswa $65 \%$ dengan nilai rata-rata 72,13 . Sedangkan pada siklus II mengalami peningkatan sangat baik yakni ketuntasan siswa 92,5\%. Dengan demikian dapat disimpulkan bahwa dengan penerapan metode silaba dapat meningkatkan keterampilan membaca permulaan siswa kelas I SDN 012 Bengkong.
\end{abstract}

Kata Kunci: Metode Silaba, Keterampilan membaca permulaan, Siswa sekolah dasar.

\begin{abstract}
Abstrak
This research is motivated by the low level of reading skills of the first grade students of SDN 012 Bengkong Batam. One solution to overcome this problem is to apply the profit method. The purpose of this study was to improve reading skills of class I students on the My Family theme by using the silaba method. This research method is Classroom Action Research (CAR) which is carried out in two cycles. Each cycle consists of two meetings and four stages namely planning, implementation, observation, reflection, and the time of the study carried out on November 20 2019-28 November 28 2019. The subject of this research is class I students, amounting to 40 people. Collection techniques in the form of documentation, observation and tests. The results of this study concluded that the students' initial reading skills with the theme of outhalu in the first cycle were classified as less effective with $65 \%$ students completeness with an average value of 72.13 . Whereas in the second cycle there was a very good increase of $92.5 \%$ students completeness. Thus it can be concluded that the application of the silaba method can improve the reading skills of the beginning of class I students at SDN 012 Bengkong.
\end{abstract}

Keywords: Silaba Method, Beginning reading skills, Elementary school students

JURNAL PENDIDIKAN DAN KONSELING VOLUME 3 NOMOR 1 TAHUN 2021 


\section{PENDAHULUAN}

Pendidikan Bahasa Indonesia merupakansalah satu aspek penting yang perlu diajarkan kepada para siswa di sekolah.Maka mata pelajaran ini kemudian diberikan sejak masih bangku Sekolah Dasar (SD) karena dari situ diharapkan siswa mampu menguasai, memahami dan dapat mengimplementasikan keterampilan berbahasa.Seperti membaca, menyimak, menulis dan berbicara.

Permendiknas No. 22 Tahun 2006,(dalam Pebriana.P : 2016), bahasa memiliki peran sentral dalam perkembangan intelektual, sosial, dan emosional peserta didik dan merupakan penunjang keberhasilan dalam mempelajari semua bidang studi. Pembelajaran bahasa diharapkan membantu peserta didik mengenal dirinya, budayanya, dan budaya orang lain, mengemukakan gagasan dan perasaan, berpartisipasi dalam masyarakat yang menggunakan bahasa tersebut, dan menemukan serta menggunakan kemampuan analitis dan imaginatif yang ada dalam dirinya.

Bahasa Indonesia sebagai bahasa persatuan dan bahasa negara di Negara Kesatuan Republik Indonesia, ini memiliki fungsi yang sangat dominan dalam segala aspek di dalam kehidupan bermasyarakat.Bahasa Indonesia adalah mata pelajaran wajib yang diajarkan di jenjang sekolah dasar.Oleh karena ini, guru dituntut untuk mampu mengembangkan pembelajaran agar siswa mampu mencapai kompetensi dasar yang telah ditetapkan.

Dalam pembelajaran Bahasa Indonesia, membaca merupakan salah satu keterampilan berbahasa yang sangat penting dikuasai agar dapat berkomunikasi secara optimal. Seseorang akan memperoleh berbagai pengetahuan baru yang mampu meningkatkan wawasannya sehingga mereka lebih mampu menjawab tantangan hidup kedepan yang semakin kompleks.

Pembelajaran Bahasa Indonesia memiliki kedudukan yang sangat penting. Bahasa Indonesia merupakan mata pelajaran yang wajib untuk semua jenjangpendidikan termasuk siswa
SD. Rahim (2007:1) berpendapat masyarakat yang gemar membaca memperoleh pengetahuan dan wawasan baru yang semakin meningkatkan kecerdasannya sehingga mereka mampu menjawab tantangan di masa depan. Salah satu keterampilan berbahasa yang sangat penting untuk dimiliki adalahketerampilan membaca.Dengan membaca, seseorang dapat membuka wawasan baru yang luas.Burns, dkk (dalam Rahim 2007:1) mengemukakan bahwa keterampilan membaca merupakan sesuatu yang vital dalam suatu masyarakat terpelajar. Namun anak-anak yang belum memahami pentingnya belajar membaca tidak akan termotivasi untuk belajar membaca.

Menurut Zuchadi dan Budiasih (dalam Ardiyanti, 2015:3) Membaca permulaan merupakan tahap awal yang didapatkan anak dalam proses belajar membaca. Membaca permulaan adalah keterampilan dasar membaca bagi siswa dan alat untuk mengetahui makna dari isi mata pelajaran yang dipelajarinya disekolah.Membaca permulaan merupakan program pembelajaran yang khusus dirancang untuk siswa kelas-kelas awal pada saat mulai memasuki sekolah dasar.Membaca ini menentukan seseorang untuk menguasai kemampuan lainnya, melalui pembelajaran membaca permulaan, siswa diharapkan mampu mengenali huruf, suku kata, kata, kalimat, dan membaca dengan lancar, karena keterampilan membaca permulaan sangat berpengaruh terhadap kelancaran dan keterampilan membaca lanjutan. Berdasarkan penjelasan diatas dapat disimpulkan keterampilan membaca permulaan akan sangat berpengaruh terhadap kemampuan membaca lanjut sebagai keterampilan yang mendasar maka keterampilan membaca permulaan benar-benar memerlukan perhatian guru.

Rahim (2007:2) mengutarakan bahwa membaca pada hakikatnya adalah sesuatu yang rumit melibatkan banyak hal, tidak hanya sekedar melafalkan tulisan, tetapi juga melibatkan aktivitas visual, berpikir, psikolinguistik dan metakognitif sebagai proses 
visual membaca merupakan penerjemahan simbol tulis (huruf) dalam kata-kata lisan.

Dalam tingkatan membaca, membaca permulaan merupakan tingkatan yang paling penting.Hal ini dikarenakan membaca permulaan merupakan kemampuan membaca dasar yang harus dikuasai anak sebelum anak melanjutkan tahapan membaca dasar yang membaca yang lebih tinggi (Hidayat, 2014:400). Brata (dalam Kumara, 2014:1) menyatakan pembelajaran membaca tingkat permulaan merupakan tingkatan proses pembelajaran membaca untuk menguasai sistem tulisan sebagai representasi visual bahasa.

Menurut Abdurahman (dalam Mulyadi, 2009:9), membaca merupakan aktivitas kompleks mencakup fisik dan mental, aktivitas fisik yang terkait dengan membaca adalah gerak mata dan ketajaman penglihatan.Orang dapat membaca dengan baik jika mampu melihat huruf - huruf secara jelas, mampu menggerakkan mata secara lincah, mengingat simbol- simbol bahasa dengan tepat dan memiliki penalaran yang cukup untuk memahami bacaan. Berdasarkan beberapa pengertian di atas dapat disimpulkan bahwa keterampilan membaca adalah kesanggupan melakukan aktivitas kompleks baik fisik maupun mental untuk meningkatkan keterampilan kerja, penguasaan berbagai bidang akademik serta berpartisipasi dalam kehidupan bemasyarakat.Berdasarkan pengalaman dan hasil penilaian keterampilan membaca siswa kelas I di MID semester I terlihat bahwa siswa belum sepenuhnya menguasai keterampilan membaca dari 40 siswa yang dinyatakan tuntas dengan Kriteria Ketuntasan Minimal (KKM) 70 hanya 17 anak $(42,5 \%)$ dan yang belum tuntas 23 anak $(57,5 \%)$ dari 17 siswa tuntas yaitu siswa yang sudah lancar membaca, sedangkan 23 yang tidak tuntas terdiri siswa kurang lancar membaca dan siswa tidak mengenal huruf, dan sulit membaca, jadi dari kurangnya keterampilan membaca siswa tersebut menimbulkan beberapa masalah.

Untuk mengetahui perkembangan keterampilan membaca permulaa pada Penelitian Tindakan Kelas (PTK) ini dilakukan berhasil apabila nilai rata-rata kelas mencapai 70, dan terdapat minimal $70 \%$ dari keseluruhan siswa telah mencapai Kriteria Ketuntasan Minimal (KKM) yakni sebesar 70.

a. Ketuntasan belajar secara klaksikal dihitung menggunakan rumus sebagai berikut:

Ketuntasan Belajar Klasikal $\underset{\text { xuogh }}{\%})=$

Setelah data terkumpul melalui observasi, data tersebut diolah dengan menggunakan rumus presentasi Sugiyono: 2004)

$$
\mathrm{P}={ }_{-} \mathrm{x} 100 \%
$$

Keterangan:

$\mathrm{F} \quad=$ Frekuensi aktivitas guru

$\mathrm{N}=$ Skor maksimal aktivitas guru

$\mathrm{P}=$ Angka presentase

$100 \%=$ Bilangan tetap

\section{HASIL PENELITIAN DAN PEMBAHASAN}

\section{A. Deskripsi Sebelum Tindakan.}

Sebelum dilakukan penelitian tindakan kelas, terlebih dahulu peneliti melakukan kegiatan belajar mengajar dengan tujuan untuk mengetahui keadaan nyata yang ada dilapangan dan permasalahan yang ada, serta peneliti menganalisis data awal Keterampilan membaca siswa pada mata pelajaran Bahasa Indonesia kelas 1 pada semester ganjil tahun ajaran 2018/2019.

Tahapan ini bertujuan untuk mengetahui seberapa tinggi tingkat keterampilan membaca permulaan siswa pada mata pelajaran Bahasa Indonesia kelas I sebelum diterapkan metode silaba. Penelitian ini berkaitan tentang rendahnya keterampilan membaca permulaan pada siswa kelas I dimana dari 40 siswa, masih ada 17 siswa yang mendapatkan nilai dibawah KKM (<65) atau 57,5\% yang belum lancar membaca Bahasa Indonesia, 
karena metode sebelumnya yang digunakan kurang efektif dimana setelah menggunakan metode tersebut, masih ada beberapa siswa yang belum bisa mengenal huruf dengan baik.

Nilai batas Kriteria Ketuntasan Minimal untuk pelajaran Bahasa Indonesia adalah 70 . Berdasarkan hal tersebut peneliti menyimpulkan keterampilan membaca permulaan siswa yang rendah perlu ditingkatkan dengan melakukan tindakan penelitian menerapkan metode silaba dalam proses pembelajaran membaca permulaan siswa pada mata pelajaran bahasa Indonesia.

\section{METODOLOGI PENELITIAN}

Subjek penelitian ini adalah guru dan siswa kelas 1 SDN 012 Bengkong Batam yang terdaftar pada tahun 2018/2019, dengan jumlah siswa 40 orang yang terdiri dari 24 orang siswa laki-laki dan 16 orang siswa perempuan.

Metode yang digunakan dalam penelitian ini adalah Penelitian Tindakan Kelas (PTK) Jenis penelitian yang akan dilakukan adalah Penelitian Tindakan Kelas (PTK).

Menurut Hamzah, dkk (2012:41) menyatakan bahwa Penelitian Tindakan Kelas adalah penelitian yang dilakukan oleh guru di dalam kelasnya sendiri melalui refleksi diri, dengan tujuan untuk memperbaiki kinerjanya sebagai guru, sehingga proses pembelajaran dapat berjalan dengan baik, dan hasil belajar siswa meningkat. penelitian ini terdiri dari dua siklus setiap siklus melakukan empat kegiatan yaitu perencanaan, pelaksanaan, observasi, dan refleksi.

\section{A. Teknik Pengumpulan data}

Data penelitian ini dikumpulkan dengan menggunakan dokumentasi, observasi, dan tes. Berikut adalah uraiannya secara rinci:

1) Teknik Dokumentasi

Menurut Sugiyono (2013:240)

dokumen merupakan catatan peristiwa

yang sudah berlalu.Dokumen bisa berbentuk tulisan, gambar, atau karya-karya monumental dari seorang.

Dokumen yang berbentuk tulisan misalnya catatan harian, sejarah kehidupan (life histories), cerita biografi, peraturan, kebijakan.Dokumen yang berbentuk gambar misalnya foto, gambar hidup, sketsa dan lainlain.Dokumen yang berbentuk karya misalnya karya seni, yang dapat berupa gambar, patung, film dan lain-lain.Studi dokumen merupakan pelengkap dari penggunaan metode observasi dan wawancara dalam penelitian kualitatif.

Teknik dokumentasi yang digunakan dalam penelitian ini berupa pengambilan foto dan video pada saat kegiatan pembelajaran berlangsung dan dokumentasi ini bertujuan untuk melihat kegiatan yang dilakukan guru dan siswa terutama pada kegiatan- kegiatan pokok dari pembelajaran membaca permulaan dengan menggunakan metode silaba.Dokumentasi digunakan untuk mengabadikan kegiatan- kegiatan penting, serta menjadi pelengkap data guna menyempurnakan penelitian yang telah dilakukan.

2) Teknik Observasi

Menurut Kunandar (2011:143) observasi adalah kegiatan pengamatan (pengambilan data) untuk memotret seberapa jauh efek tindakan telah mencapai sasaran.

Teknik observasi yang digunakan dalam penelitian ini dilaksanakan dengan mengamati aktivitas siswa dan guru dalam proses pembelajaran. Penggunaan teknik observasi ini bertujuan untuk mengetahui sejauh mana tindakan penerapan metode silaba dan mengetahui bagaimana aktivitas guru dan siswa selama proses pembelajaran berlangsung.

3) Teknik tes

Tes adalah salah satu alat ukur

untuk menentukan keberhasilan dalam proses pembelajaran. Arikunto (2010: 193) mengatakan bahwa tes merupakan serentetan pertanyaan yang digunakan 
untuk mengukur keterampilan, pengetahuan maupun kemampuan yang dimiliki oleh individu maupun kelompok.Tes yang diberikan pada penelitian ini untuk mengetahui sejauh mana meningkatkan keterampilan membaca siswa setelah penerapan metode silaba.Dalam penelitian ini tes dilakukan pada akhir siklus pembelajaran.

\section{SIMPULAN}

Berdasarkan hasil penelitian dan pembahasan yang telah dilaksanakan selama II siklus dapat disimpulkan bahwa "Melalui Metode Silaba dapat meningkatkan Keterampilan membaca permulaan pada mata pelajaran Bahasa Indonesia Siswa kelas I di SDN 012 Bengkong”.

Berdasarkan hasil pengamatan proses pembelajaran II siklus ini dan nilai keterampilan membaca permulaan siswa dengan menggunakan metode silaba telah memenuhi kriteria indikator keberhasilan yang diharapkan pada penelitian ini. Maka pembelajaran dengan menggunakan metode silaba dapat meningkatkan keterampilan membaca permulaan siswa.

Hasil tes keterampilan membaca siswa mengalami peningkatkan dengan diterapkannya metode silaba. Pada siklus I jumlah siswa yang baik adalah sebanyak 26 orang siswa atau sebesar $65 \%$ sedangkan pada siklus II jumlah siswa yang kategori baik lebih banyak dari siklus satu yakni 37 orang siswa atau sebesar 92,5\% Dengan demikian penerapan metode silaba dapat meningkatkan keterampilan membaca siswa SDN 012 Bengkong.

Pada pembelajaran membaca permulaan menggunakan metode silaba dapat meningkatkan keterampilan membaca permulaan siswa kelas I SD dan dapat sebagai bahan acuan untuk mengadakan penelitian selanjutnya. Selain itu dapat diimplementasikan sebagai bahan kajian pendekatan pembelajaran bagi guru untuk diterapkan di SDN 012 Bengkong sebagai alternative dalam mata pelajaran bahasa Indonesia membaca permulaan.

Berdasarkan hasil penelitian dan kesimpulan, maka peneliti sampaikan beberapa implikasi sebagai berikut:

\section{Manfaat Teoritis}

Hasil penelitian ini telah
memberikan informasi berkaitan
dengan metode silaba untuk
meningkatkan keterampilan membaca
permulaan siswa.

2. Manfaat Praktis

a. Bagi Siswa

Menerapkan Metode Silaba ternyata dapat meningkatkan keterampilan membaca permulaan siswa. Oleh karena itu dalam upaya meningkatkanketerampilan membaca permulaan dengan menggunakan metode silaba bisa terus dikembangkan dalam proses pembelajaran membaca permulaan siswa kelas 1 .

\section{b. Bagi Guru}

Penerapan Metode Silaba dalam pembelajaran membaca permulaan di kelas 1 bisa dijadikan alternatif pilihan agar pembelajaran membaca dapat dilakukan dengan baik dan dapat dijadikan pedoman dalam kegiatan pembelajaran membaca permulaan.

Oleh karena itu pihak sekolah pro aktif memfasilitasi segala kebutuhan guru dan siswa dalam upaya meningkatkan mutu layanan pendidikan.Dan lagi bagi peneliti sendiri agar lebih banyak lagi memberikan pembelajaran kepada para siswa dengan variasi metode pembelajaran yang mampu meningkatkan keterampilan membaca siswa.

\section{c. Bagi Sekolah}

Sebagai informasi untuk kajian lebih lanjut dalam meningkatkan kualitas pembelajaran di sekolah, terutama dalam meningkatkan keterampilan

JURNAL PENDIDIKAN DAN KONSELING VOLUME 3 NOMOR 1 TAHUN 2021 
membaca permulaan pada mata pelajaran bahasa Indonesia kelas I SDN 012 Bengkong.

\section{d. Bagi Peneliti}

Mendapatkan pengalaman baru dalam proses pembelajaran dikelas dengan menggunakan metode pembelajaran yang bervariasi dari pembelajaran sebelumnya

\section{DAFTAR PUSTAKA}

Ardiyanti, L. (2015). Peningkatan Keterampilan Membaca Permulaan Melalui Metode Kata Lembaga Siswa Kelas 1 SD Karanggayam Kecamatan Pleret Kabupaten

Bantul.(Skripsi). Universitas Negeri Yogyakarta.Yogyakarta

Arikunto. (2010). Prosedur Penelitian

Suatu Pendekatan Praktik. Jakarta: Rineka Cipta

Hamzah, dkk. (2013). Assesment Pembelajaran.Jakarta: Bumi

Aksara

Hidayat, R. (2014). Meningkatkan Kemampuan Membaca Permulaan Melalui Metode Silaba Untuk Anak Berkesulitan Belajar Kelas 2 SD Negeri 09 Koto Luar Padang. Jurnal Ilmiah Pendidikan Khusus Vol.3 (1):Hal 400-401

Kunandar. (2011). Langkah Mudah Penelitian Tindakan Kelas Sebagai Pengembangan Profesi

Guru.Jakarta : Rajawali Pers

Pebriana, P.H (2017). Peningkatan Keterampilan Menulis Puisi Bebas Menggunakan Pendekatan Kontekstual Siswa Sekolah Dasar Jurnal Publikasi PendidikanVol 7 (Hal : 95) 